\title{
Arsenic content in two-year-old Acer platanoides L. and Tilia cordata Miller seedlings growing under dimethylarsinic acid exposure-model experiment
}

\author{
Sylwia Budzyńska ${ }^{1} \cdot$ Piotr Goliński $^{1}$ • Przemysław Niedzielski ${ }^{2} \cdot$ Monika Gąsecka $^{1}$ - Mirosław Mleczek ${ }^{1}$
}

Received: 29 August 2018 / Accepted: 28 December 2018 / Published online: 11 January 2019

(C) The Author(s) 2019

\begin{abstract}
The presence of cacodylic acid (dimethylarsinic acid, DMA) can be an important factor in limiting the abilities of young tree seedlings to adapt to unfavorable environmental conditions. For this reason, the aim of the study was to estimate the influence of different DMA additions (from 0.01 to $0.6 \mathrm{mM}$ ) to modified Knop solution to arsenic (As) and selected forms of this metalloid (As(III), As(V), DMA) phytoextraction by two-year-old Acer platanoides L. and Tilia cordata Miller seedlings. Additionally, the biomass and other elements important in As transport in plants were analyzed. Seedlings of both tree species were able to grow in all experimental systems except the one with the highest DMA concentration $(0.6 \mathrm{mM})$. Exposure of tree seedlings was related to a general decrease in plant biomass. Phytoextraction of As in roots, stems, and leaves increased with a rise of DMA concentration in solution to the highest content of As in A. platanoides and T. cordata roots growing under $0.3 \mathrm{mM}(135 \pm 13$ and $116 \pm$ $14 \mathrm{mg} \mathrm{kg}^{-1}$ dry weight). Arsenic was accumulated mainly in roots, thereby confirming bioconcentration factor values BCF $>1$ for all tree seedlings treated with DMA. Exposure of plants to low DMA concentrations $(0.01$ and $0.03 \mathrm{mM})$ was related to the transport of this element to aboveground parts, while increased DMA concentration in other experimental systems led to the limitation of As transport to stems, as confirmed by translocation factor values $\mathrm{TF}<1$. Changes in many other elements such as boron, silicon, phosphorus, or sulfur concentration indicated the possible influence of DMA on the transport of As from roots to leaves. The obtained results show that DMA can be an important factor in modulating As phytoextraction in the studied tree species.
\end{abstract}

Keywords Arsenite $\cdot$ Arsenate $\cdot$ Cacodylic acid $\cdot$ Phytoextraction $\cdot$ Trees

\section{Introduction}

The chemistry of arsenic (As) in the environment is complex due to the many different chemical forms of this metalloid that occur (Geiszinger et al. 2002; Upadhyay et al. 2018). Current

Responsible editor: Elena Maestri

Electronic supplementary material The online version of this article (https://doi.org/10.1007/s11356-018-04121-x) contains supplementary material, which is available to authorized users.

Sylwia Budzyńska

sylwia.k.budzynska@gmail.com

1 Department of Chemistry, Poznań University of Life Sciences, Wojska Polskiego 75, 60-625 Poznań, Poland

2 Faculty of Chemistry, Adam Mickiewicz University, Umultowska 89, 61-614 Poznań, Poland studies mostly emphasize inorganic As forms which are predominant in aerobic and anaerobic soils, arsenite (As(III)), and arsenate $(\mathrm{As}(\mathrm{V}))$, respectively ( $\mathrm{Li}$ et al. 2016; Abbas et al. 2018), where As(III) is considered as more soluble, mobile, and cytotoxic than $\mathrm{As}(\mathrm{V})$, (Chandrakar et al. 2016). On the other hand, the most common organic forms of As in soils are monomethylarsonate (MMA) and dimethylarsinate (DMA), (Fitz and Wenzel 2002; Feldmann et al. 2018). Speciation of As is dynamic because of the inter-conversion of As(III) and $\mathrm{As}(\mathrm{V})$ through redox cycling and methylation to organic forms (Abbas and Meharg 2008). Methylation is the process of replacing one or more hydroxyl ligands (-OH) by a methyl group $\left(-\mathrm{CH}_{3}\right)$ in inorganic As structures (Paul et al. 2015) and it is a well-characterized detoxification mechanism in a wide range of organisms from bacteria to mammals and probably in plants also (Abbas and Meharg 2008; Lomax 2013).

According to, e.g., Carbonell-Barrachina et al. (1999), Bergqvist and Greger (2014), or Zhang et al. (2017), inorganic 
forms of As are treated as more harmful than organic forms to living organisms. It is worth underlining, however, that some researchers have found organic As to be more toxic compared to inorganic forms (Mandal and Suzuki 2002; Yamanaka et al. 2004; Yoon et al. 2015). There is increasing evidence to suggest that methylated metabolites of As cause oxidative stress, cytotoxicity, and may be carcinogenic for exposed organisms (Nigra et al. 2017). The possible higher toxicity of DMA in relation to $\mathrm{As}(\mathrm{III})$ or $\mathrm{As}(\mathrm{V})$ has been described, e.g., in one of our most recent studies (Budzyńska et al. 2017b, 2018), where two-year-old seedlings of Ulmus laevis and Acer platanoides were exposed to $\mathrm{As}(\mathrm{III}), \mathrm{As}(\mathrm{V})$, and DMA forms in a pot experiment. $U$. laevis and A. platanoides seedlings were not able to survive under DMA, while in the case of inorganic forms, the growth of trees was not disturbed. For this reason, to expand our knowledge of the role of DMA in the soil, the influence of this As form on plant survivability as well as on the phytoextraction of other As forms or other elements, it is necessary to examine the unique toxic properties of DMA.

Information about inorganic compounds has dominated in investigations of As in soils, whereas organic As compounds, which are sometimes found as minor components of soil, can also reach high concentrations (Singh et al. 2015). Methylated As forms have been detected, e.g., in acidic fen soil (Huang and Matzner 2006), in agricultural soil from cotton-producing areas (Bednar et al. 2002), in the orchard, upland, and paddy soils (Takamatsu et al. 1982) as well as in peat (Zaccone et al. 2018). DMA was the second most common organic As species (after arsenobetaine, AsB) in the forest floor, up to $0.006 \mathrm{mg} \mathrm{DMA} \mathrm{kg}^{-1}$, which was $12 \%$ of the total extractable As detected by Huang and Matzner (2007). An interesting fact is that the half-life of DMA is about 20 days and 31 days in untreated and As-amended soils, respectively (Abbas and Meharg 2008).

The mechanisms of $\mathrm{As}(\mathrm{III})$ and $\mathrm{As}(\mathrm{V})$ uptake and toxicity in plants are generally understood, but those for DMA are less well elucidated (Meharg and Hartley-Whitaker 2002). Abedin et al. (2002) first showed that uptake of DMA has a slow rate, was concentration dependent, and could be described by linear functions and the Michaelis-Menten kinetics model. Additionally, Abbas and Meharg (2008) found a much lower rate of DMA influx in plants when compared to As(III) and As $(V)$, and they confirmed the possibility to describe some parameters using the Michaelis-Menten model. A similar concentration-dependent influx of DMA and well-described uptake by the model mentioned above was shown for rice Oryza sativa L. by Rahman et al. (2001).

There is evidence that DMA is a highly mobile form within the plant, more effectively translocated from root to the shoots than other As forms (Faroog et al. 2016). Raab et al. (2007) showed tenfold higher shoot/root translocation factors (TFs) than those of $\mathrm{As}(\mathrm{V})$ in 46 investigated plant species from 13 different families. High rates of DMA readily translocated from roots to shoots were also described, e.g., in grass Spartina alterniflora by Carbonell et al. (1998a, 1998b), in tomato Lycopersicum esculentum by Burló et al. (1999), in radish Raphanus sativus by Tlustoš et al. (2002), in pepper Capsicum annum L. by Szákova et al. (2007), in turnip Brassica napus L. by Carbonell-Barrachina et al. (1999) and Yao et al. (2009), in mustard Sinapis alba by Jedynak et al. (2010), and in castor bean Ricinus communis by Ye et al. (2010) as well as in rice O. sativa L. by Marin et al. (1992) and Carey et al. (2011). Higher translocation of DMA can be explained by the lack of a complex with thiols such as phytochelatin (PC) formation (Raab et al. 2007).

The aim of the study was to determine the phytoextraction efficiency of As and its selected forms (As(III), As(V), and DMA) in two-year-old seedlings of Acer platanoides L. and Tilia cordata Miller growing in Knop solution enriched with different dimethylarsinic acid (DMA) concentrations. Plants were characterized by their biomass and concentration of particular As forms and calcium $(\mathrm{Ca})$, potassium $(\mathrm{K})$, magnesium $(\mathrm{Mg})$, and sodium $(\mathrm{Na})$ in roots, stems, and leaves of seedlings. Additionally, analyses of boron (B) and silicon (Si) content, elements important in As(III) transport and also phosphorus (P) and sulfur (S), and elements crucial in $\mathrm{As}(\mathrm{V})$ transport were performed. This study is a response to the question to our previous work of the real role of DMA to survivability, adaptation, biomass crop, As, and other elements phytoextraction by organs of selected tree species (Budzyńska et al. 2017b, 2018). Presence of DMA in the environment can be an important factor limited to survivability of studied young tree species and finally their use in phytoremediation practice.

\section{Materials and methods}

\section{Characteristics of experimental materials}

Experimental plant materials were obtained from the forest nursery of the Pniewy Forest Division $\left(52^{\circ} 29^{\prime} 4^{\prime \prime} \mathrm{N} ; 16^{\circ} 15^{\prime}\right.$ $28^{\prime \prime}$ E) on 20 March 2017. Two-year-old leafless seedlings of A. platanoides L. (Norway maple) and T. cordata Miller (Linden) used in the experiment were characterized by mean biomass of $99.6 \pm 3.7$ (range from 88.8 to $106.9 \mathrm{~g}$ ) and $82.5 \pm$ $2.2 \mathrm{~g}$ (range from 77.5 to $86.9 \mathrm{~g}$ ), respectively. All seedlings were planted in the experiment in such a way that the mean biomass of plants growing in a particular experimental system was almost the same.

\section{Experiment design}

Seedlings of A. platanoides L. and T. cordata Miller were brought from the forest nursery in pots $(15 \times 15 \mathrm{~cm}$, diameter $\times$ height) filled with organic garden soil and removed for 10 days to start leaf growth. During this time, each plant was 
watered with the same amount of deionized water. Afterwards, the plants were washed with distilled water to remove soil particles from the root systems. The plants were then dried with paper towels and weighed to estimate their biomass before the experiment. The seedlings were planted on 27 March 2017 in white cylindrical pots $(21 \times 21 \mathrm{~cm}$, diameter $\times$ height $)$ filled with $1.5 \mathrm{~kg}$ of ultrapure quartz sand (content of $\mathrm{SiO}_{2}>97 \%$, $\mathrm{pH}=7.18$, particle size range was $1-3 \mathrm{~mm}$ ). One plant was placed in one pot. Seven experimental systems (control; $\mathrm{DMA}_{0.01} ; \mathrm{DMA}_{0.03} ; \mathrm{DMA}_{0.06} ; \mathrm{DMA}_{0.1} ; \mathrm{DMA}_{0.3}$ and $\mathrm{DMA}_{0.6}$ ) were prepared for each tree species using the following concentration of DMA $\left(\left(\mathrm{CH}_{3}\right)_{2} \mathrm{As}(\mathrm{O}) \mathrm{OH}\right)$ : 0 (control); $0.01 ; 0.03 ; 0.06$; $0.1 ; 0.3$; and $0.6 \mathrm{mM}$ in modified Knop solution (Barabasz et al. 2010). 1 L of Knop solution per pot and six plants for each experimental system were used. The reason for the use of such concentrations of DMA was based on the results of our previous studies (Budzyńska et al. 2017b, 2018). The mean values of temperature, moisture, and concentration of $\mathrm{CO}_{2}$ were $24.8 \pm 2{ }^{\circ} \mathrm{C}, 43 \pm 3 \%$, and $474.7 \pm 1.5 \mathrm{ppm}$, respectively during the 3 -month long pot experiment. The plants were automatically watered with deionized water during the experiment to provide seedlings with the support of a similar mean level of the solution. Addition of water in this way allowed us to limit evapotranspiration and an extreme increase of DMA presence in the space of roots.

\section{Sample preparation and biomass analysis}

At the end of the experiment, seedlings of both tree species were carefully washed with deionized water, dried with paper towels, and divided into parts (roots, stems, and leaves) to estimate their final biomass and calculate the percentage biomass increase during the experiment. Next, all parts were dried at $105 \pm 2{ }^{\circ} \mathrm{C}$ for $48 \mathrm{~h}$ (leaves) and $120 \mathrm{~h}$ (stems and roots) using an electric drier SLW 53 STD (Pol-Eko, Wodzisław Śląski, Poland). Plant parts from particular experimental systems were then ground for $0.5 \mathrm{~min}$ in a Cutting Mill SM 200 (Retsch GmbH, Haan, Germany). Accurately weighed $0.300 \pm 0.001 \mathrm{~g}$ of dry powder samples of plant parts were placed into a glass flask containing $10 \mathrm{~mL}$ of phosphoric acid (1 M) and extracted in an ultrasonic bath $(30 \mathrm{~min}$ at ambient temperature). The solution was then filtered using a paper filter washed by $200 \mathrm{~mL}$ of water. The arsenic species and total As concentration were determined immediately after the extraction procedure.

\section{Arsenic speciation studies}

The procedure of As speciation studies has been described in previous work (Niedzielski et al. 2013). The arsenic forms (As(III), As(V), DMA, respectively) were determined by high performance liquid chromatography with hydride generation atomic absorption spectrometry detection (HPLC-HG-AAS).
The determination limits were found at the level of $0.1 \mathrm{mg} \mathrm{kg}^{-1}$ for all forms determined. Due to a lack of certified reference materials for As speciation in samples extracted by phosphoric acid, the standard addition method was used for accuracy and traceability studies. Recoveries at the level 80$120 \%$ were found as satisfactory.

\section{Determination of As, B, Ca, K, Mg, Na, P, S, and Si in tree parts}

The inductively coupled plasma optical emission spectrometer Agilent 5110 ICP-OES (Agilent, USA) was used in As, B, Ca, $\mathrm{K}, \mathrm{Mg}, \mathrm{Na}, \mathrm{P}, \mathrm{S}$, and $\mathrm{Si}$ determination. A synchronous vertical dual view (SVDV) of the plasma was accomplished with dichroic spectral combiner (DSC) technology which allows the axial and radial view to be analyzed simultaneously. Common instrumental conditions were applied: radio frequency (RF) power $1.2 \mathrm{~kW}$, nebulizer gas flow $0.7 \mathrm{~L} \mathrm{~min}^{-1}$, auxiliary gas flow 1.0 $\mathrm{L} \mathrm{min}{ }^{-1}$, plasma gas flow $12.0 \mathrm{~L} \mathrm{~min}^{-1}$, charge coupled device (CCD) temperature $-40{ }^{\circ} \mathrm{C}$, viewing height for radial plasma observation $8 \mathrm{~mm}$, accusation time $5 \mathrm{~s}, 3$ replicates. The content of S for selected samples was checked with a FLASH 2000 analyzer (Thermo Scientific) with FPD detector. Traceability was verified using the standard addition methods, and recoveries at the level of 80-120\% were found as satisfactory. General characteristics of fundamental analytical data are present in supplementary data (Table S1).

\section{Statistical analysis and calculations}

The obtained results were analyzed using STATISTICA 12.0 software (StatSoft, USA). To compare biomass, elements, or As form contents in parts of both tree species growing in all experimental systems, one-way analysis of variance (ANOVA) followed by the post-hoc Tukey HSD test was applied. Additionally, to compare both total seedling biomass, biomass of plant parts, or elements accumulated in parts of plants growing under the same experimental system, the significances $\left({ }^{*} p<0.05,{ }^{* *} p<0.01,{ }^{* * *} p<0.001\right)$ between plants treated with the same DMA addition were determined using a Student's test. To show the real potential of seedlings of two tree species growing under particular experimental systems for phytoextraction of As, the total content of this metalloid in the total biomass was calculated taking under consideration As content in particular parts and biomass of roots, stems, and leaves.

To determine the ability of the analyzed tree seedlings to uptake As from Knop solution to the plant, the bioconcentration factor $(\mathrm{BCF})$ was calculated as a ratio of $\mathrm{As}_{\text {total }}$ in stem and leaves to the concentration of this metalloid in solution. Concerning As transport inside the plants, the translocation factor (TF) was calculated as the ratio of the concentration of $\mathrm{As}_{\text {total }}$ in aboveground parts and the concentration of this element in roots (Ali et al. 2013). 


\section{Results}

Both A. platanoides and T. cordata seedlings were unable to grow in Knop solution enriched with $0.6 \mathrm{mM}$ of DMA $\left(\mathrm{DMA}_{0.6}\right.$ system). These plants were characterized by their leaves withering within just 5 ( T. cordata) and 8 (A. platanoides) days of the beginning of the experiment.

\section{Seedling biomass and development}

The similar seedling biomass of $A$. platanoides and $T$. cordata planted in particular experimental systems at the beginning had become diverse by the end of the experiment, as shown in Fig. 1. The mean percentage increase of total seedling biomass growing in subsequent systems was as follows: 29.9; $15.4 ; 16.2 ; 11.4 ; 5.2$ and $2.9 \%$ (A. platanoides) and 20.2; $10.9 ; 10.8 ; 6.0 ; 3.0$ and $2.3 \%$ (T. cordata). The highest biomass was characterized by the control seedlings of A. platanoides (132.9 g).

In accordance with DMA concentration increase in subsequent Knop solutions (experimental systems), lower increases of plant biomass than those of the control were observed for both tree species. The biomass of $A$. platanoides and T. cordata seedlings growing under $\mathrm{DMA}_{0.3}$ system (105.1 and $82.9 \mathrm{~g}$, respectively) was characterized by the lowest biomass increase in relation to control plants (132.9 and $99.2 \mathrm{~g}$, respectively), which pointed to the more significant negative influence of DMA on A. platanoides than T. cordata biomass (79.1 and $83.6 \%$ of control seedlings biomass, respectively). These results are reflected in the diversity of biomass of the tree species parts. In the case of $A$. platanoides, the biomass of root, stem, and leaves of plants growing under $\mathrm{DMA}_{0.3}$ system was 58.3; 93.6; and $1.7 \%$ of control plants, respectively, while for $T$. cordata it was $74.5 ; 107.5$; and $51.8 \%$, respectively of the control. These results have shown that the addition of DMA had a particularly negative influence on A. platanoides leaves, while exposure of T. cordata to DMA was related to insignificant stem biomass stimulation.

To compare the development of seedlings growing under particular experimental systems, the morphological characteristics of tree seedlings after 90 days of the experiment are shown in Fig. 2. Additionally, characteristics of these plants after 45 days of the experiment (Fig. S1) are presented in Supplementary material.

Negative symptoms of DMA influence were observed after 14 and 19 days from the start of the experiment for A. platanoides and T. cordata, respectively. It is worth emphasizing that these negative symptoms (brown leaf spots, turning leaves) were characteristic of seedlings of both tree species growing under $\mathrm{DMA}_{0.03}$ system only. Moreover, seedlings of both tree species exposed to the $\mathrm{DMA}_{0.03}$ system were characterized by almost the same shape and size of leaves, while leaves of plants growing under $\mathrm{DMA}_{0.01}$ or $\mathrm{DMA}_{0.06}$ systems were smaller in size (Fig. 2).

\section{Content of As in plant parts}

Exposure of seedlings of the studied tree species to increased DMA concentration in the experimental systems was related to an increase of As content in their roots, stems, and leaves (Fig. 3). Exceptions were leaves of A. platanoides and stems of $T$. cordata growing under the $\mathrm{DMA}_{0.3}$ system, where an insignificantly lower content of As than for plants under the $\mathrm{DMA}_{0.1}$ system was recorded. The highest content of As was observed in A. platanoides roots growing under the $\mathrm{DMA}_{0.3}$ system $\left(135 \pm 13 \mathrm{mg} \mathrm{kg}^{-1} \mathrm{DW}\right)$, which was of a significantly higher value than in the roots of $T$. cordata growing under the same experimental system $\left(116 \pm 14 \mathrm{mg} \mathrm{kg}^{-1} \mathrm{DW}\right)$. A similar tendency for roots of seedlings growing under other experimental systems, except plants exposed to the $\mathrm{DMA}_{0.03}$ system, was observed, where the content of As in roots of the two
Fig. 1 Characteristics of whole biomass and plant parts $[\mathrm{g}]$ of A. platanoides and T. cordata seedlings after experiment

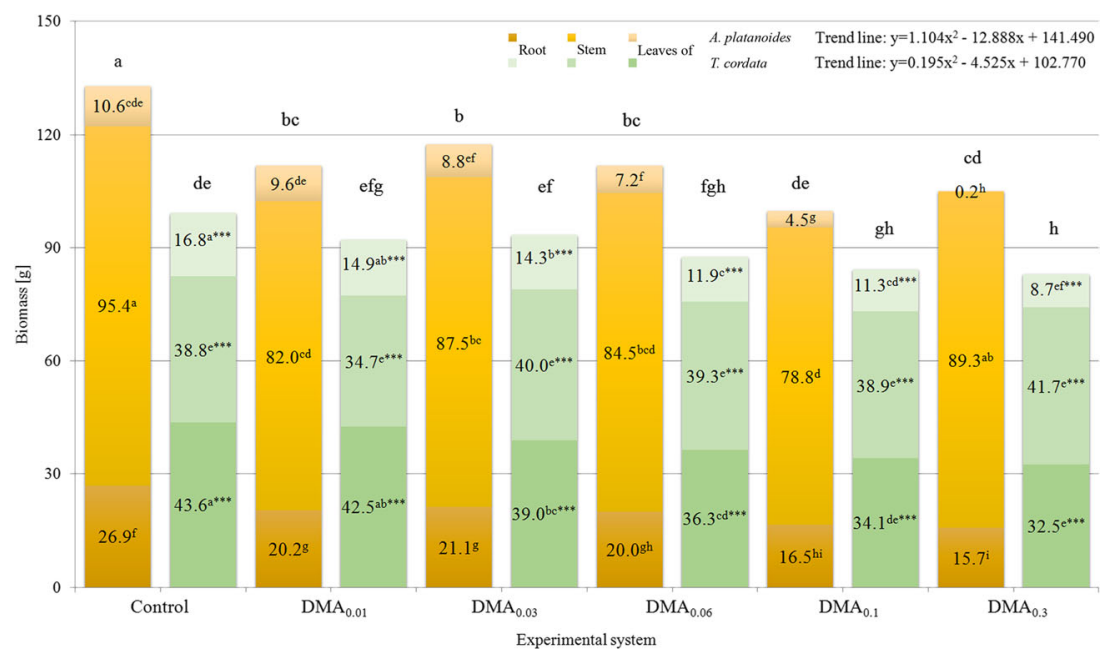


Fig. 2 Morphological presentation of seedlings of tree species after experiment

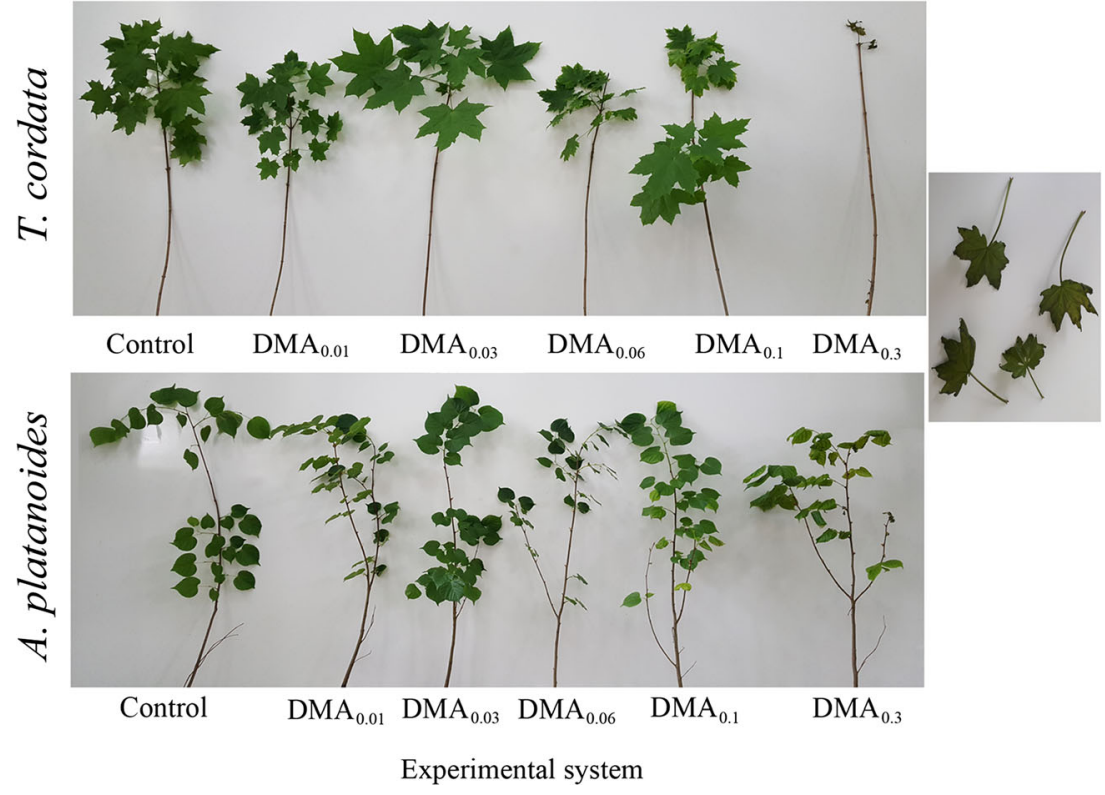

tree species was almost the same. An increase of As content in A. platanoides stems was present, while for T. cordata similar tendency was observed except plants growing under the $\mathrm{DMA}_{0.3}$ system. The opposite situation was noted for leaves, where only $T$. cordata leaves were characterized by a constant increase of As content in the all the subsequent experimental systems. The content of As in A. platanoides leaves was significantly higher for seedlings growing in all experimental systems than in $T$. cordata leaves.

Content of As in roots, stems, and leaves of $A$. platanoides growing under the $\mathrm{DMA}_{0.3}$ system was 3870,4633 , and $5139 \%$, respectively, while for $T$. cordata it was 6118,8500 , and $9323 \%$, respectively of the As content in parts of control seedlings, which points to the high efficiency of As phytoextraction in the parts of the studied tree species.

The content of As in the whole biomass of tree seedlings rose with increased concentration of this metalloid in Knop solution (Fig. 4a). The highest content of As was recorded in A. platanoides and $T$. cordata seedlings growing under the $\mathrm{DMA}_{0.3}$ system $(4.97 \pm 0.68$ and $4.41 \pm 0.49 \mathrm{mg}$ per plant, respectively). An especially significant increase of As content in seedlings of both tree species growing under the $\mathrm{DMA}_{0.03}$ and $\mathrm{DMA}_{0.06}$ system was observed. The high efficiency of As accumulation confirmed BCF values $>1$ for both tree species and experimental systems, except $A$. platanoides seedlings growing under $\mathrm{DMA}_{0.01}$. Effective transport of As from the root system to aerial parts of seedlings described by $\mathrm{TF}>1$ values was only recorded for $A$. platanoides and $T$. cordata growing under $\mathrm{DMA}_{0.01}$ and $\mathrm{DMA}_{0.03}$.

To show differences in As content in particular parts of plants, the percentage share of As content in parts in relation to As content in the whole plant was calculated separately for A. platanoides (Fig. 4b) and T. cordata (Fig. 4c).
In control seedlings of both tree species, roots contained the greatest amount of $\mathrm{As}$ (61.1 and $83.7 \%$ of $\mathrm{As}_{\text {total }}$, respectively). The addition of the lowest doses of DMA into Knop medium caused As to be transported mainly to stems with only limited As transport to roots, especially for seedlings growing under the $\mathrm{DMA}_{0.01}$ and $\mathrm{DMA}_{0.03}$ systems. With progressively higher concentrations of DMA, the amount of As deposited in roots became higher. This tendency was similar in A. platanoides and T. cordata seedlings but with different proportions of As content in particular parts (Fig. 4b, c).

\section{Characteristics of As forms in tree seedling parts}

Differences in As phytoextraction and transport to aboveground parts of the two tree species are reflected in differences in the content of As forms. Depending on the organ, DMA concentration in solution and tree species, the content of $\mathrm{As}(\mathrm{III}), \mathrm{As}(\mathrm{V})$, and DMA was diverse. In the case of roots of A. platanoides, a dominant As form was As(III) with the other forms taking a similar share (Fig. 5). In stems, especially in plants exposed to higher concentrations of DMA (DMA ${ }_{0.06}$, $\mathrm{DMA}_{0.1}$, and $\mathrm{DMA}_{0.3}$ systems), As(III) was a dominant form with a large share of $\mathrm{As}_{\mathrm{org}}$ and $\mathrm{As}(\mathrm{V})$. In leaves of seedlings growing under these systems, the dominant forms were $\mathrm{As}$ (III) and $\mathrm{As}_{\text {org }}$ (Detailed results are presented in Table S2 of Supplementary material). It is worth emphasizing that the As form added to the medium was DMA, present in roots of A. platanoides, while the content of this As form in stem and leaves was marginal when compared to $\mathrm{As}_{\text {total }}$.

As(III) was also dominant in the roots of T. cordata seedlings but unlike $A$. platanoides seedlings there was an insignificantly lower content of $\mathrm{As}_{\text {org }}$ and lower content of $\mathrm{As}(\mathrm{V})$ and DMA (Fig. 6). Stems of T. cordata seedlings contained 


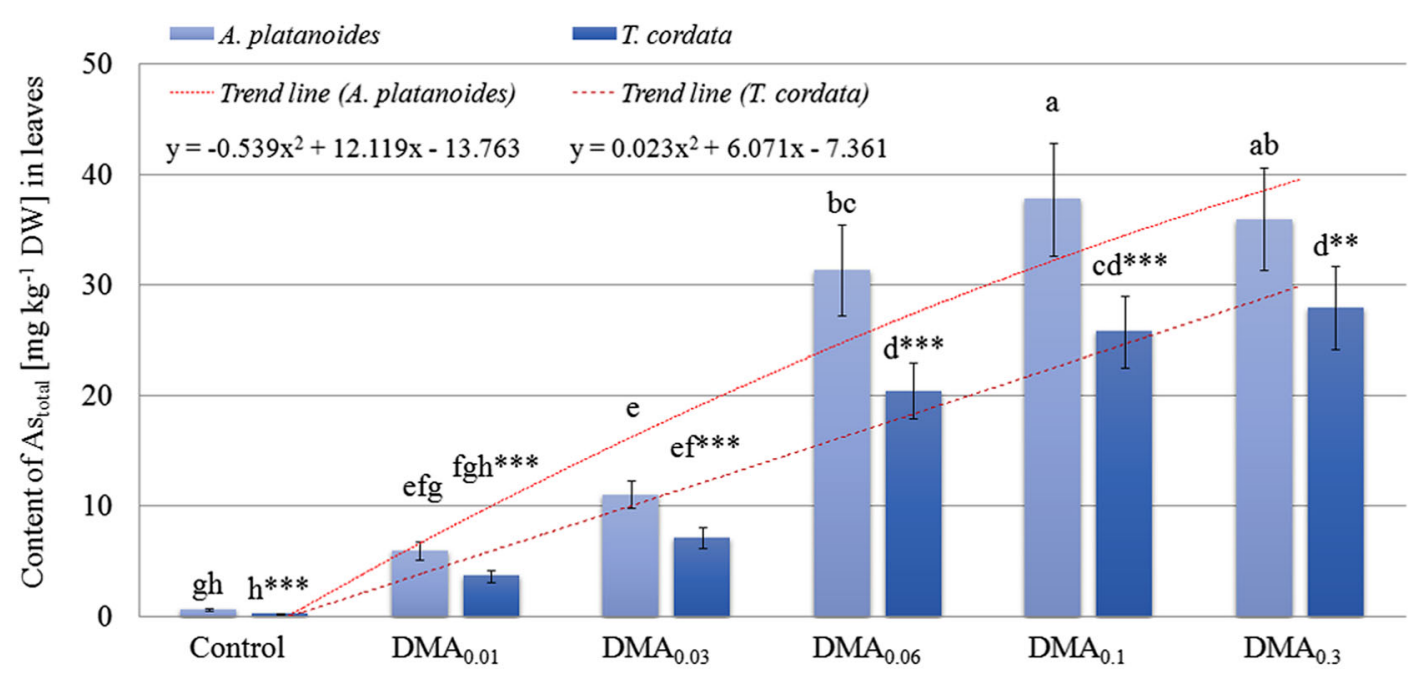

Experimental system

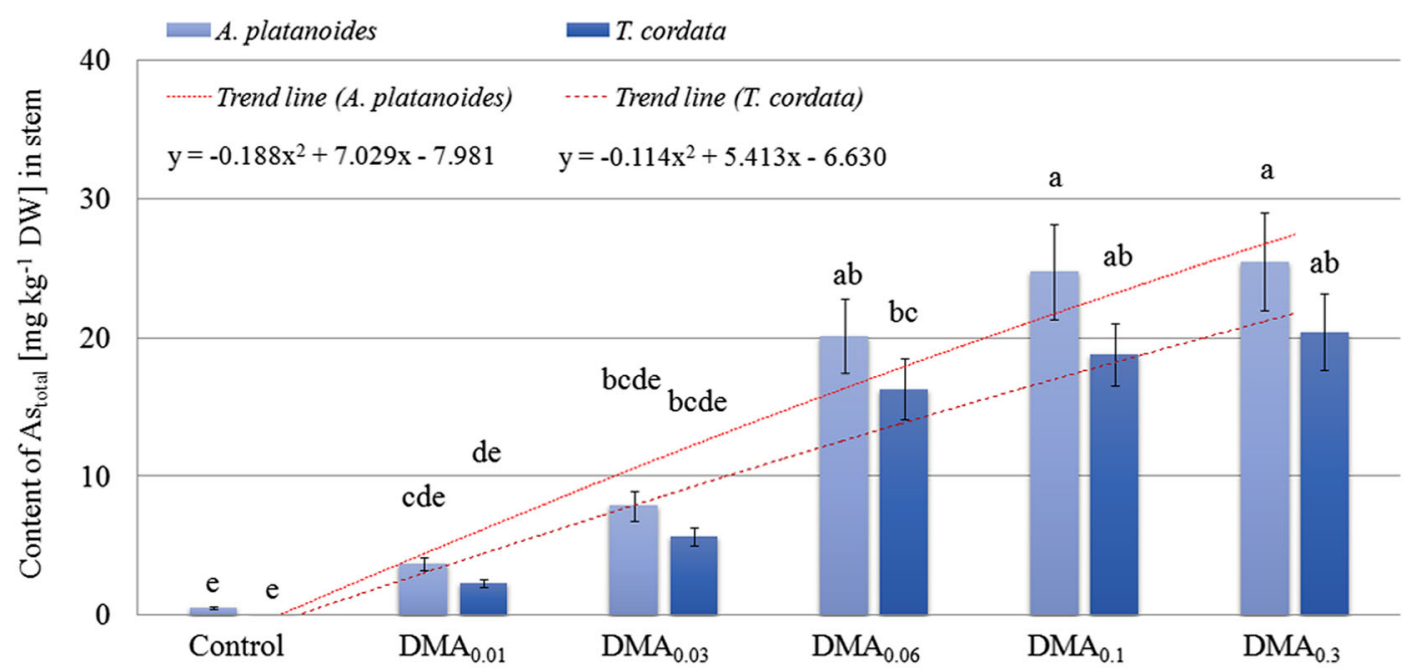

Experimental system

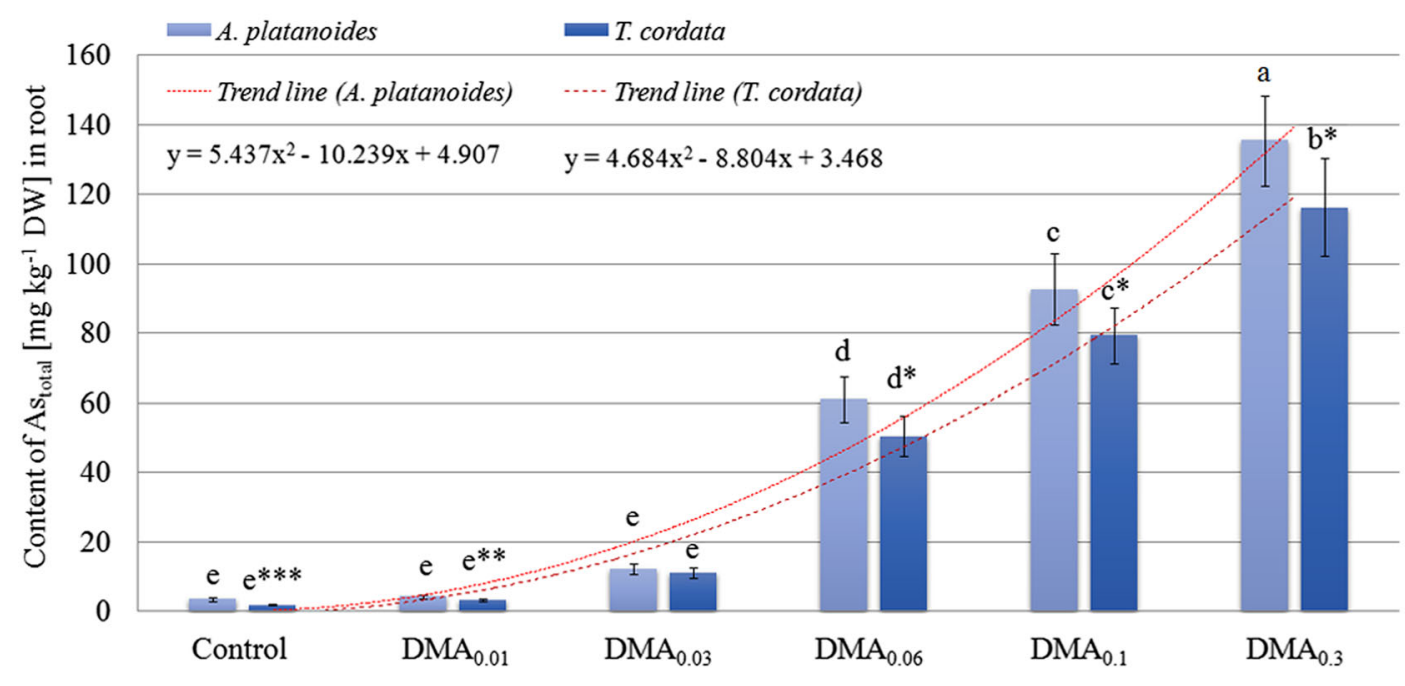

Experimental system

Fig. 3 Content of As $\left[\mathrm{mg} \mathrm{kg}^{-1} \mathrm{DW}\right]$ in root, stem, and leaves of A. platanoides and T. cordata seedlings 


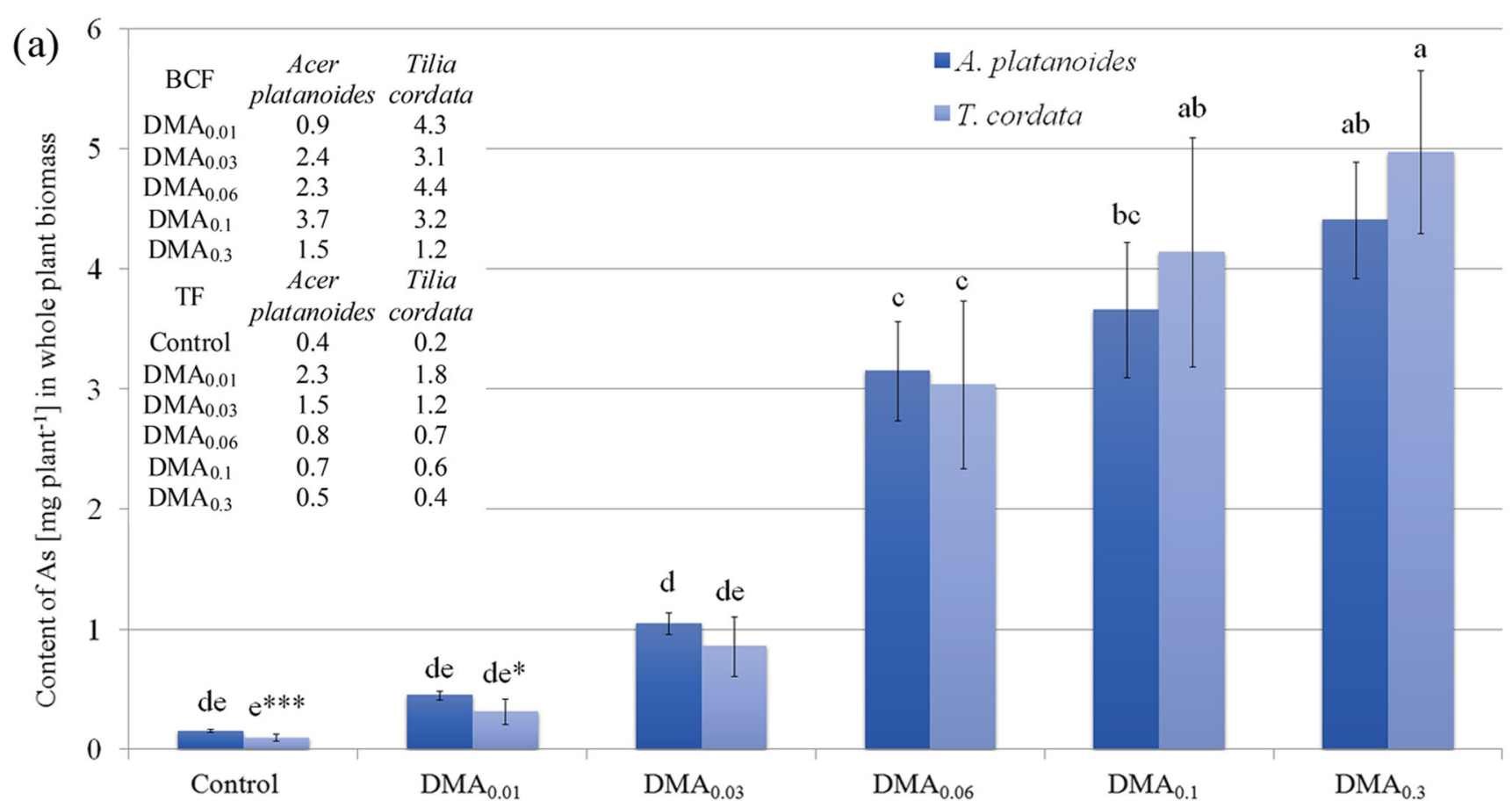

Experimental system

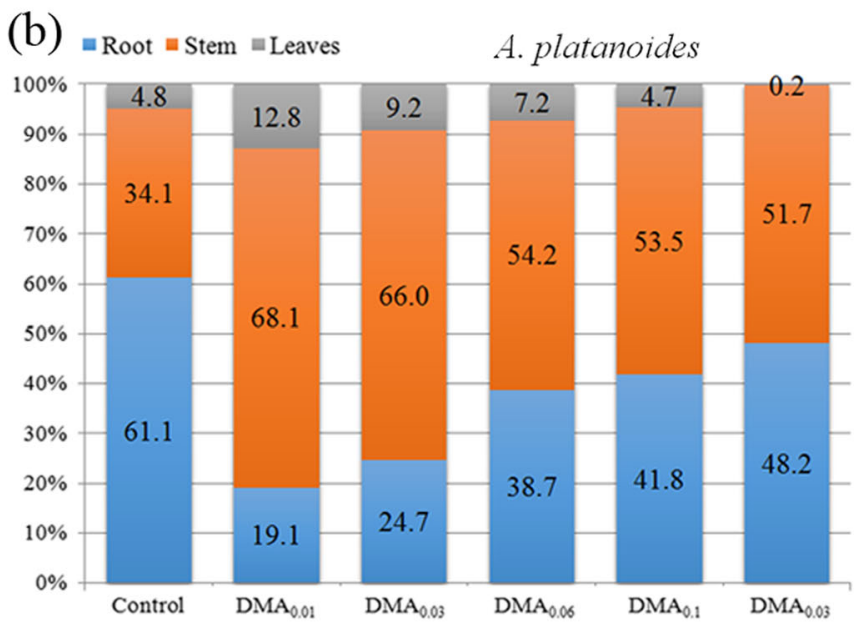

Experimental system (c) $\approx$ Root $\equiv$ Stem $\approx$ Leaves $\quad$ T. cordata

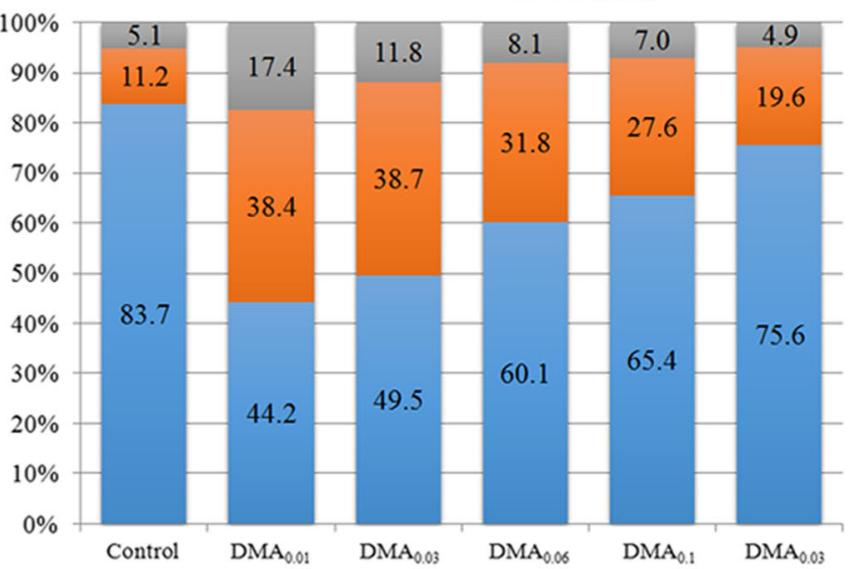

Experimental system

Fig. 4 Content of (a) As [mg per plant] with bioaccumulation factor (BCF) and translocation factor (TF) values and percentage distribution of $\mathrm{As}_{\text {total }}$ in plant parts of (b) A. platanoides and (c) T. cordata

mainly As(III). Interestingly, the leaves of this tree species were characterized by the presence of all the studied As forms, especially $\mathrm{As}(\mathrm{III})$ and DMA but also $\mathrm{As}(\mathrm{V})$ and $\mathrm{As}_{\text {org }}$ in similar low amounts (Table S3 in Supplementary material).

\section{Characteristics of other elements content in tree species parts}

Seedlings of both tree species were also characterized by the content of $\mathrm{B}, \mathrm{Ca}, \mathrm{K}, \mathrm{Mg}, \mathrm{Na}, \mathrm{P}, \mathrm{Si}$, and $\mathrm{S}$ in their parts. A full description of the results is presented in Tables S4 and S5 in
Supplementary material. The content of B in leaves of A. platanoides and $T$. cordata was almost identical, while in the stem and roots of both tree species, it decreased with an increase of DMA concentration in Knop solution (Table S4). Almost the same response was observed in the studied tree species for $\mathrm{Na}$ and $\mathrm{Si}$, where a corresponding increase and decrease of the content of these elements in the following experimental systems was recorded in all parts. The content of $\mathrm{Ca}$ and $\mathrm{K}$ in A. platanoides leaves; $\mathrm{Ca}, \mathrm{K}$, and $\mathrm{Mg}$ in T. cordata leaves; and $\mathrm{Ca}$ and $\mathrm{K}$ in $T$. cordata roots decreased with the increase of DMA addition to solution. The content of 


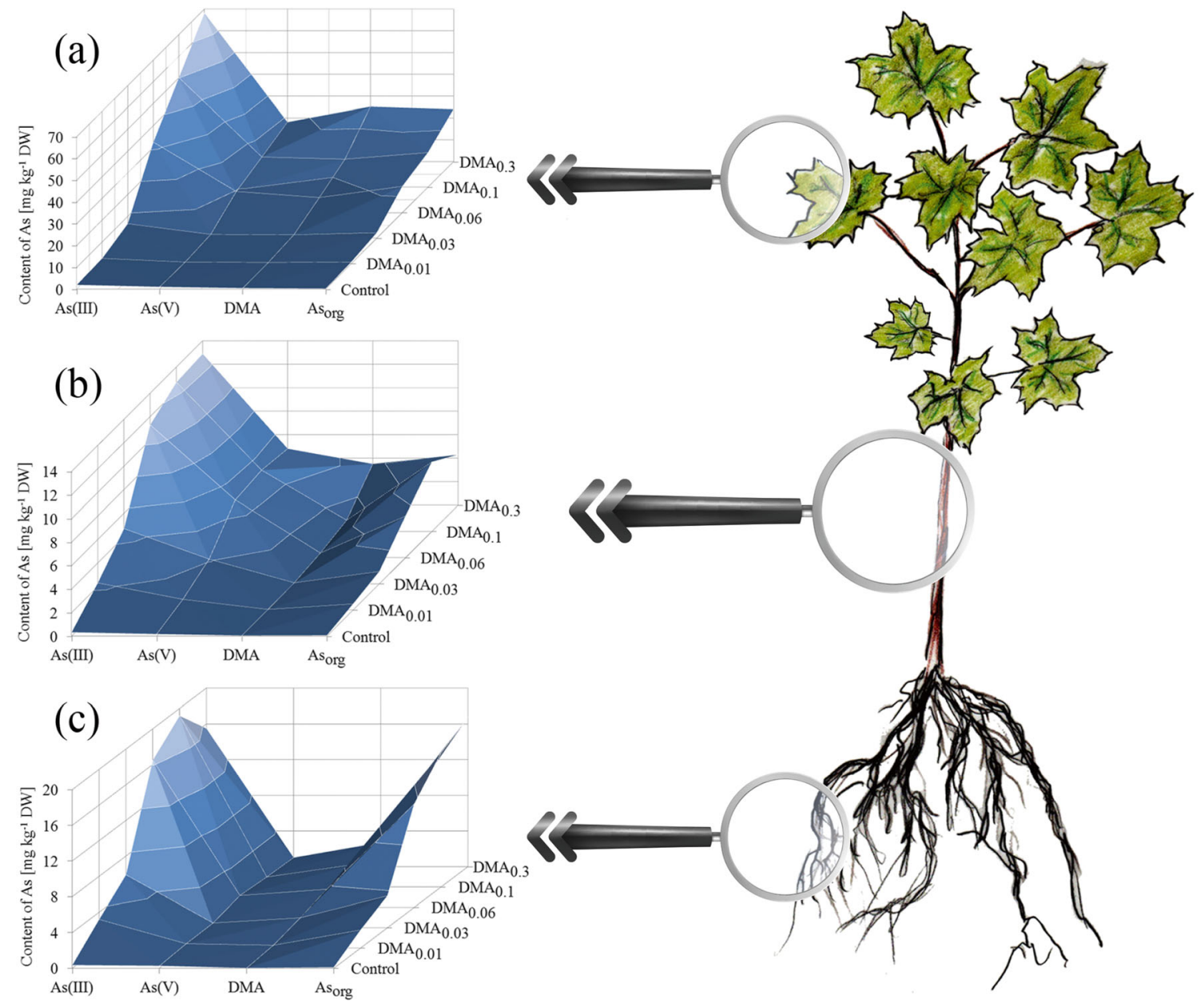

Fig. 5 Content of As forms [mg kg-1 DW] in (a) leaves, (b) stem, and (c) roots of A. platanoides seedlings

$\mathrm{Ca}, \mathrm{K}$, and $\mathrm{Mg}$ in A. platanoides roots rose with an increase of DMA concentration in solution, which was a decidedly opposite tendency to that observed for T. cordata. An increase of $\mathrm{Ca}, \mathrm{K}$, and $\mathrm{Mg}$ in A. platanoides stems and a decrease of $\mathrm{Ca}$ and $\mathrm{Mg}$ content in T. cordata stems were also observed (Table S4). It is worth to underline that similarities in the response of both tree species to increased concentrations of DMA in Knop solution were found for P and S (Table S5). The decrease in the content of these elements in roots and stems was noted except $\mathrm{S}$ in A. platanoides roots, where no significant differences were observed for plants growing in particular experimental systems.

\section{Discussion}

Generally, the presence of As in a substrate is related to an unfavorable influence on plant growth and development (Kumar et al. 2018). Our experiment was designed to examine how DMA can influence young seedlings of selected tree species. Budzyńska et al. (2017b) described the differences in phytoextraction of As and the forms this metalloid during exposure of $U$. laevis seedlings to 21 experimental systems with single, double, and triple addition of $\mathrm{As}(\mathrm{III}), \mathrm{As}(\mathrm{V})$, and/or DMA. Seedlings of $U$. laevis were only unable to grow under exposure to DMA addition at a concentration of $0.6 \mathrm{mM}$, similarly to the results presented in this paper. The dominant inorganic As forms in aerobic and reducing environment are As(V) and As(III) forms, respectively (Yanitch et al. 2017), however, the share of organic forms of As can be up to $30 \%$ of the mobile fraction in the unpolluted forest floor (Huang and Matzner 2007). Both of these forms are toxic to living organisms and can easily enter the food chain (Santra et al. 2013). Organic forms of As, characterized by lower toxicity, can also be present in edible parts of vegetables or other plants (Sadee et al. 2016). MMA and DMA are As forms that have a lower share than inorganic forms in total As concentration in soil (Bakhat et al. 2017), but their toxicity, especially of DMA, is still open to discussion (Suriyagoda et al. 2018).

\section{Growth of trees under DMA exposition}

The presence of As in a plant can cause significant changes in its physiology, morphology, and biochemistry; 


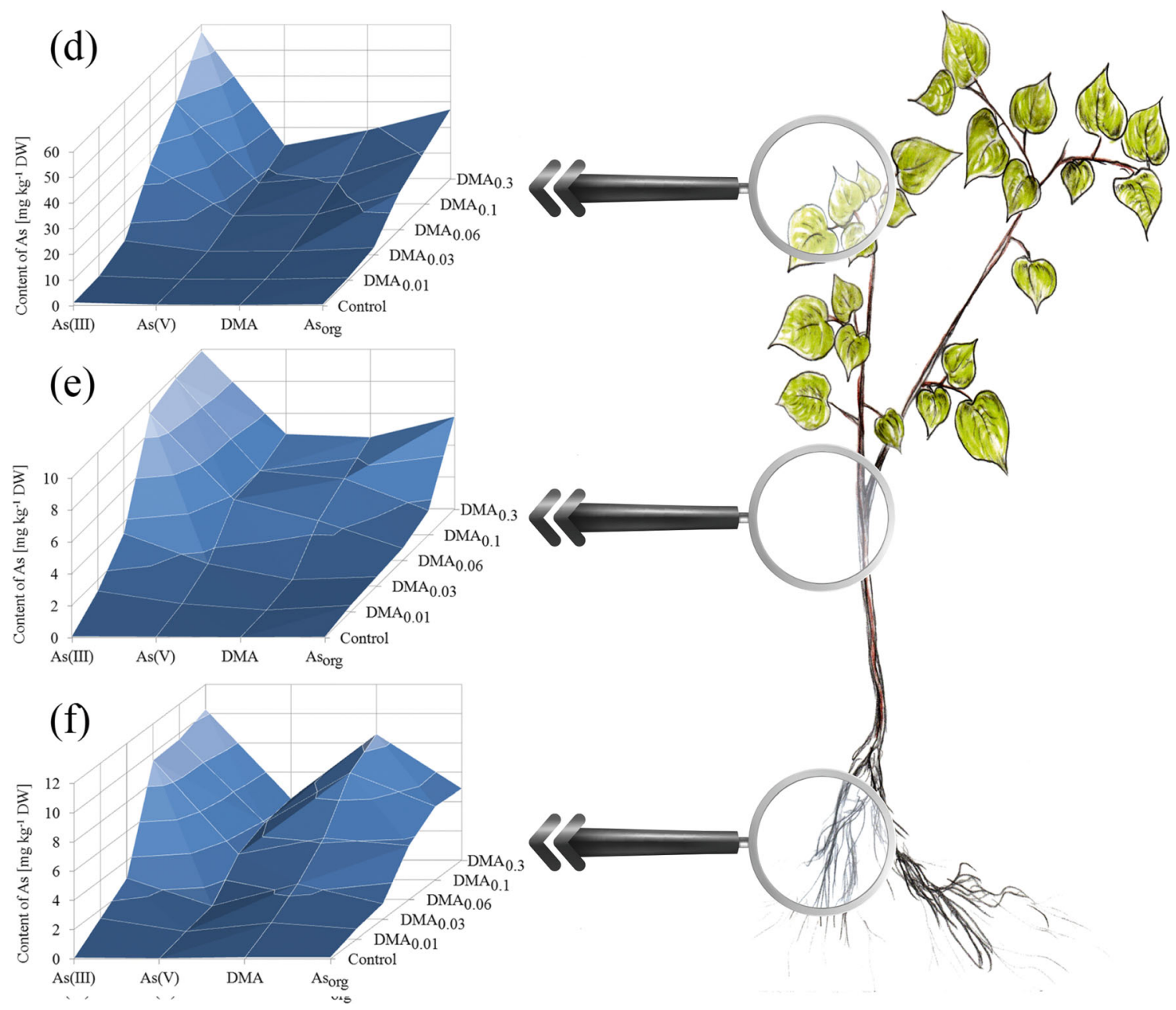

Fig. 6 Content of As forms [mg kg-1 DW] in (a) leaves, (b) stem, and (c) roots of T. cordata seedlings

therefore, in excess, this metalloid negatively affects plant growth and biomass crop (Abbas et al. 2018). The toxic influence of DMA on germination has been described in numerous papers (Duncan et al. 2017), while other papers have suggested that there is no negative influence of this As form (Yoon et al. 2015). Comparison of the As forms most often present is different, e.g., As(V) > As(III) >> DMA for Zea mays L. (Mohamed et al. 2008), As(III) > DMA $>\mathrm{As}(\mathrm{V})$ for selected cultivated plant species (Yoon et al. 2015), or DMA $>\mathrm{As}(\mathrm{V})>\mathrm{MMA}$ for A. thaliana (Tang et al. 2016). In the case of the latter, toxic influence of As forms was dependent on the time of exposure (DMA > As(V) > MMA in 20-day and MMA > $\operatorname{DMA}(\mathrm{V})>\operatorname{As}(\mathrm{V})$ in 11-day agar plate experiments), which suggests that toxic effect of DMA is related to plant exposure time. In our 3-month experiment, the toxic influence of DMA could be higher than in the experiment of Tang et al. (2016). Additionally, concentrations of DMA used in the experiments were higher, which can negatively influence both plant biomass and As uptake. Biomass of $A$. platanoides and $T$. cordata seedlings decreased with an increase of DMA concentration in Knop solution. This indicated the negative influence of this As form on plants, but differences between the control and treated seedlings were slight when compared to the effect of this form on other plants, e.g., Hordeum vulgare and Triticum aestivum (Yoon et al. 2015) or A. thaliana (Tang et al. 2016). The lowest biomass of roots and leaves of radish exposed to DMA was described by Tlustoš et al. (2002) with similar As content in both parts. Of course, the radish is not a tree, but it clearly shows the negative influence of DMA on plant growth. A decrease of leaf surface after DMA exposure was described by Marin et al. (1993) in O. sativa L. cv. 'Mercury', which corresponds to our observation. We have no data on the response of trees to DMA, but our results are similar to many other literature data, where tree species were exposed to As(III) and/or As(V). Each time, a decrease of tree biomass was observed despite varying efficiency of As uptake with an increased gradient in the concentration of this metalloid in the substrate (Yanitch et al. 2017). 


\section{Phytoextraction and translocation of As forms}

It is well known that the efficiency of As phytoextraction is mainly dependent on the forms of this metalloid in a substrate, their concentration, bioavailability, and plant species (Carbonell et al. 1998b; Kuehnelt et al. 2000; Tlustoš et al. 2002). One problem of plant response exposed to different DMA concentrations is related to the possible transformation of As forms mainly in roots and stem (Mishra et al. 2017). Exposure of plants to $\mathrm{As}(\mathrm{V})$ or MMA is usually related to a greater concentration of As in roots than in aboveground parts, while the opposite situation is observed during DMA presence (Chandra et al. 2018; Ye et al. 2010). In our studies, the highest amount of As was deposited in roots of both tree species, and the dominant form was As(III) in all parts both of A. platanoides and T. cordata. When comparing the content of $\mathrm{As}_{\text {total }}$ in parts of these tree species with many other literature data, the described values were relatively high; especially when we take into consideration the slow uptake of DMA in relation to $\mathrm{As}(\mathrm{III})$ or $\mathrm{As}(\mathrm{V})$ from solution to roots according to the results of Mishra et al. (2017) who found that As phytoextraction was lower when plants were exposed to DMA compared to inorganic As forms.

Exposure of plants to only inorganic As forms is usually related to the presence of inorganic forms in plant tissues (Jedynak et al. 2010); however, Budzyńska et al. (2017a) recorded slight amounts of DMA mainly in roots of A. platanoides L., Betula pendula Roth., Quercus robur L., and $U$. laevis Pall, while Tlustoš et al. (2002) found DMA in roots and leaves of radish. When we compare results described by Raab et al. (2007) for 46 plant species growing under $\mathrm{As}(\mathrm{V}), \mathrm{MMA}$, and DMA, separately it is quite easy to show that abilities of plants to translocate DMA, generally characterized with higher mobility, are different. Some examples are Colocasia esculenta, Vicia faba L., O. sativa L. var. Bala, or Thunbergia alata Bojer ex Sims, where exposure to DMA was each time related with a higher As concentration in roots than in shoots. It worth underlining that Raab et al. (2007) have shown a tendency for all studied plants jointly, as was the case for Ye et al. (2010), who recorded the same pathway of As transport during DMA exposure. Liao et al. (2016) studied interactions between As and phenanthrene in P. vittata L. parts found that exposure of plants to As(III) and DMA separately was not caused significantly higher As concentration in pinnae, while exposure to $\mathrm{As}(\mathrm{V})$ was related with a significantly higher content of As in this organ. This could be an effect of a significantly higher content of this metalloid in roots.

On the other hand, contents of $\mathrm{As}_{\text {total }}$ and DMA in tree parts were correlated corresponding to an increase of DMA concentration in Knop solution; the same observation was described by Bakhat et al. (2017). It suggests that the studied tree species effectively accumulated DMA in all parts in proportion to the concentration of this As form in solution. Seedlings of both tree species growing under $\mathrm{DMA}_{0.01}$ and $\mathrm{DMA}_{0.03}$ systems were characterized by $\mathrm{BCF}$ and $\mathrm{TF}$ values higher than 1 ; evidence of the effective uptake of As and translocation of this metalloid to the stem and finally to leaves. Higher concentrations of DMA in Knop solution caused limited As transport to aboveground parts, while uptake of As to roots was still intensive. This points to the influence of DMA on plant biomass (Fig. 2.) and changes in the content of nutritional elements mainly in roots, e.g., potassium in $T$. cordata roots, which in part corresponds to results obtained by Gomes et al. (2012) who studied the savanna tree Anadenanthera peregrina.

In the case of rice, Mishra et al. (2017) found the dominant form of As during exposure of $O$. sativa $\mathrm{L}$. to DMA to be just such a form with a marginal share of inorganic As forms in both roots and shoots. We did not observe such a tendency for A. platanoides and T. cordata, which suggests that As phytoextraction takes place in a different way to many other plant species. Our knowledge about the real nature of DMA and its influence on tree response is still very restricted (Mitra et al. 2017). Abedin et al. (2002) indicated a slow uptake rate of this As form, and a limited description of DMA uptake by Michaelis-Menten kinetics can suggest that this form could affect different plant species in other ways. Slow transport of methylated As forms from the rhizosphere to roots of tree species may be related with their accumulation mainly in roots with the limitation of their transport to aboveground parts such as leaves or needles (Kuehnelt et al. 2000). The possible cause of the lower DMA concentration in leaves than in roots during tree seedling exposure to this As form could also be a high content of organic As forms $\left(\mathrm{As}_{\mathrm{org}}\right)$. According to Phillips (1990), methylated As forms can be metabolized to arsenosugars and organo phospholipids, which in the case of the studied tree species was "hidden" as As org.

Duncan et al. (2017) have shown that DMA in wheat was transported via Si acid channels and confirmation of this fact was a $40 \%$ decrease in Si content. In our experiment, the decrease in Si contents in A. platanoides and T. cordata were diverse as regards the experimental system. For the highest concentration of DMA ( $\mathrm{DMA}_{0.3} \mathrm{mM}$ system), contents of $\mathrm{Si}$ in roots, stems, and leaves were 68,58 , and $59 \%$, respectively of the control in A. platanoides seedlings and 66, 53, and 38\%, respectively of the control for $T$. cordata, which also suggests the possible use of $\mathrm{Si}$ acid channels in these both tree species (Budzyńska et al. 2017a). Abbas et al. (2018) showed organic methylated As forms can be transported from the substrate to plant (xylem) via the Si influx (Lsi1) and Si efflux transporters (Lsi2). Bienert et al. (2008) and Ma et al. (2008) also named OsLsi1 (OsNIP2; 1) as an As transporter in the process of DMA influx.

Interestingly, a decrease in B content was also observed (Table S4). In the case of exposure of A. platanoides and T. cordata seedlings to the $\mathrm{DMA}_{0.3} \mathrm{mM}$ system, contents of 
$\mathrm{B}$ in roots, stems, and leaves were 53, 51, 89 and 53, 30, 83\%, respectively of those of the control tree species. Such a high decrease may suggest that besides Si transporters, B transporters also participate in DMA uptake from solution. A higher reduction of $\mathrm{B}$ and $\mathrm{Si}$ content in the $T$. cordata stem was observed than in A. platanoides, which could explain the higher content of DMA in aboveground parts of this tree species. Of course, a decrease in B and/or Si content, especially in roots may also be an effect of As(III) presence as the main form of As. On the other hand, such a great decrease in the content of these elements has to be related to the utilization of $\mathrm{B}$ and/or Si transporters in DMA uptake. A similar situation was also observed for $\mathrm{P}$ and $\mathrm{S}$, elements important in $\mathrm{As}(\mathrm{V})$ transport in numerous plants (Zhang et al. 2010; Rasas-Castor et al. 2014). In this case, a decrease in these elements was not as spectacular, which could be the effect of lower contents of just these As forms in tree parts in relation to the other As forms (Figs. 5 and 6). Disturbances in S which plays an important role in binding As(III) to sulfhydryl groups in GSH and PC, together with P (substitution of inorganic phosphate (Pi) by $\mathrm{As}(\mathrm{V})$ ) can significantly restrict plant development or survivability. Tang et al. (2016) indicated that DMA was more toxic for A. thaliana than $\mathrm{As}(\mathrm{V})$ or MMA, where a detoxication mechanism is focused on complexation with PC, thiol production, and vacuolar sequestration. In our experiment, there was a decrease of S content in roots and stems with an increase of available DMA, which may suggest that a similar mechanism of thiol production could be characteristic for the studied tree species. Additionally, Tang et al. (2016) found that the described mechanism of detoxification is ineffective for DMA, although the highest used DMA concentration was $0.2 \mathrm{mM}$, while in our experiment the toxicity was up to $0.6 \mathrm{mM}$. The similarities in A. thaliana and A. platanoides or $T$. cordata in plant response and differences in the presence of signs of toxicity are an effect of different plant species and their biomass. In our opinion, the observed changes in $\mathrm{P}$ and $\mathrm{S}$ content were related more with $\mathrm{As}(\mathrm{V})$ presence in plant tissue than negative changes in their metabolism.

\section{Conclusions}

Arsenic, which is becoming an ever-increasing source of environmental pollution, requires the use of an effective method of removal. The share of DMA in numerous post-industrial wastes is slight when compared with the total concentration of As, but the presence of this form may seriously limit the ability of plants in As phytoextraction, growth and development, or even adaptation. In our experiment, DMA caused a general decrease of plant biomass and an increase in As content in parts of A. platanoides and T. cordata that corresponded with higher concentrations of this As form in solution. Seedlings of both tree species exposed to DMA were characterized by the highest deposition of As in roots and effective uptake of this metalloid, independently of the DMA concentration. On the other hand, the addition of DMA higher than $0.03 \mathrm{mM}$ resulted in significantly more efficient phytoextraction of As with limitation in its transport to aerial parts, as confirmed by $\mathrm{TF}<$ 1. The $0.6 \mathrm{mM}$ addition of DMA was lethal for two-year-old tree seedlings, while plants exposed to the same concentration of $\mathrm{As}(\mathrm{III})$ or $\mathrm{As}(\mathrm{V})$ in solution, were still able to grow, which confirms the findings of our previous studies. It suggests that a higher share of DMA in the total concentration of As in substrate polluted with As can negatively influence the uptake of this element and plant development.

Acknowledgements This study is part of a $\mathrm{PhD}$ thesis by Sylwia Budzyńska. The authors would also like to thank the staff of the Pniewy Forest Divison and Mr. Tomasz Wajsowicz for their help.

Funding Information This study was financially supported by the National Science Centre of Poland under grant code Opus 2014/15/B/ NZ9/02172 for Piotr Goliński.

Open Access This article is distributed under the terms of the Creative Commons Attribution 4.0 International License (http:// creativecommons.org/licenses/by/4.0/), which permits unrestricted use, distribution, and reproduction in any medium, provided you give appropriate credit to the original author(s) and the source, provide a link to the Creative Commons license, and indicate if changes were made.

Publisher's Note Springer Nature remains neutral with regard to jurisdictional claims inpublished maps and institutional affiliations.

\section{References}

Abbas G, Murtaza B, Bibi I, Shahid M, Niazi NK, Khan MI, Amjad M, Hussain M (2018) Arsenic uptake, toxicity, detoxification, and speciation in plants: physiological, and molecular aspects. Int J Env Res Pub He 15:59. https://doi.org/10.3390/ijerph15010059

Abbas MHH, Meharg AA (2008) Arsenate, arsenite and dimethyl arsenic acid (DMA) uptake and tolerance in maize (Zea mays L.). Plant Soil 304:277-289. https://doi.org/10.1007/s11104-008-9549-9

Abedin MJ, Feldmann J, Meharg AA (2002) Uptake kinetics of arsenic species in rice (Oryza sativa L.) plants. Plant Physiol 128:1120 1128. https://doi.org/10.1104/pp.010733

Ali H, Khan E, Anwar SM (2013) Phytoremediation of heavy metals concepts and applications. Chemosphere 91:869-881. https://doi. org/10.1016/j.chemosphere.2013.01.075

Bakhat HF, Zia Z, Fahad S, Abbas S, Hammad HM, Shahzad AN, Abbas F, Alharby H, Shahid M (2017) Arsenic uptake, accumulation and toxicity in rice plants: possible remedies for its detoxification: a review. Environ Sci Pollut Res 24:9142-9158. https://doi.org/10. 1007/s11356-017-8462-2

Barabasz A, Krämer U, Hanikenne M, Rudzka J, Antosiewicz DM (2010) Metal accumulation in tobacco expressing Arabidopsis halleri metal hyperaccumulation gene depends on external supply. J Exp Bot 61:3057-3067. https://doi.org/10.1093/jxb/erq129

Bednar AJ, Garbarino JR, Ranville JF, Wildeman TR (2002) Presence of organoarsenicals used in cotton production in agricultural water and soil of the southern United States. J Agric Food Chem 50:7340 7344. https://doi.org/10.1021/jf025672i 
Bergqvist C, Greger M (2014) Phytostabilization of arsenic. In: Budschuh J, Hollander HM, Ma LQ (eds) In-situ remediation of arseniccontaminated sites. CRC Press, London, pp 53-67

Bienert GP, Thorsen M, Schüssler MD, Nilsson HR, Wagner A, Tamás MJ, Jahn TP (2008) A subgroup of plant aquaporins facilitate the bidirectional diffusion of $\mathrm{As}(\mathrm{OH})_{3}$ and $\mathrm{Sb}(\mathrm{OH})_{3}$ across membranes. BMC Biol 6:26. https://doi.org/10.1186/1741-7007-6-26

Budzyńska S, Krzesłowska M, Niedzielski P, Goliński P, Mleczek M (2017a) Arsenite phytoextraction and its influence on selected nutritional elements in one-year-old tree species. Microchem J 133: 530-538. https://doi.org/10.1016/j.microc.2017.04.022

Budzyńska S, Magdziak Z, Goliński P, Niedzielski P, Mleczek M (2018) Arsenic forms in phytoextraction of this metalloid in organs of 2year-old Acer platanoides seedlings. Environ Sci Pollut Res 25: 27260-27273. https://doi.org/10.1007/s11356-018-2739-y

Budzyńska S, Mleczek M, Goliński P, Rutkowski P, Niedzielski P (2017b) The influence of as forms in substrate on the phytoextraction of this metalloid in Ulmus laevis pall organs - pot experiment. Microchem J 132:333-340. https://doi.org/10.1016/j. microc.2017.01.030

Burló F, Guijarro I, Carbonell-Barrachina AA, Valero D, MartinezSánchez F (1999) Arsenic species: effects on and accumulation by tomato plants. J Agric Food Chem 47:1247-1253. https://doi.org/ $10.1021 / \mathrm{jf} 9806560$

Carbonell AA, Aarabi MA, DeLaune RD, Gambrell RP, Patric WH (1998a) Arsenic in wetland vegetation: availability, phytotoxicity, uptake and effects on plant growth and nutrition. Sci Total Environ 217:189-199. https://doi.org/10.1016/S0048-9697(98)00195-8

Carbonell AA, Aarabi MA, DeLaune RD, Gambrell RP, Patric WH (1998b) Bioavailability and uptake of arsenic by wetland vegetation: effect on plant growth and nutrition. J Environ Sci Heal A 33:45-66. https://doi.org/10.1080/10934529809376717

Carbonell-Barrachina AA, Burló F, Valero D, López E, Martinez-Romero D, Martinez-Sánchez F (1999) Arsenic toxicity and accumulation in turnip as affected by arsenic chemical speciation. J Agric Food Chem 47:2288-2294. https://doi.org/10.1021/jf981040d

Carey AM, Norton GJ, Deacon C, Scheckel KG, Lomni E, Punshon T, Guerinot ML, Lanzirotti A, Newville M, Choi Y, Price AH, Meharg AA (2011) Phloem transport of arsenic species from flag leaf to grain during grain filling. New Phytol 192:87-98. https://doi.org/ 10.1111/j.1469-8137.2011.03789.x

Chandra S, Saha R, Pal P (2018) Assessment of arsenic toxicity and tolerance characteristics of bean plants (Phaseolus vulgaris) exposed to different species of arsenic. J Plant Nutr 41:340-347. https://doi.org/10.1080/01904167.2017.1385801

Chandrakar V, Naithani SC, Keshavkant S (2016) Arsenic-induced metabolic disturbances and their mitigation mechanisms in crop plants: a review. Biologia 71:367-377. https://doi.org/10.1515/biolog2016-0052

Duncan EG, Maher WA, Foster SD, Krikowa F, O'Sullivan CA, Roper MM (2017) Dimethylarsenate (DMA) exposure influences germination rates, arsenic uptake and arsenic species formation in wheat. Chemosphere 181:44-54. https://doi.org/10.1016/j.chemosphere. 2017.04.043

Faroog MA, Islam F, Ali B, Najeeb U, Mao B, Gill RA, Yan G, Siddique KHM, Zhou W (2016) Arsenic toxicity in plants: cellular and molecular mechanisms of its transport and metabolism. Environ Exp Bot 132:42-52. https://doi.org/10.1016/j.envexpbot. 2016.08.004

Feldmann J, Bluemlein K, Krupp EM, Mueller M, Wood BA (2018) Metallomics study in plants exposed to arsenic, mercury, selenium and sulphur. In: Arruda M (ed.) Metallomics. Advances in Experimental Medicine and Biology 1055:67-100. Springer, Cham. https://doi.org/10.1007/978-3-319-90143-5_4

Fitz WJ, Wenzel WW (2002) Arsenic transformations in soil-rhizosphereplant system: fundamentals and potential application to phytoremediation. J Biotechnol 99:259-278. https://doi.org/10. 1016/S0168-1656(02)00218-3

Geiszinger A, Goessler W, Kosmus W (2002) Organoarsenic compounds in plants and soil on top of an ore vein. Appl Organomet Chem 16: 245-249. https://doi.org/10.1002/aoc.294

Gomes MP, Duarte DM, Miranda PL, Barreto LC, Matheus MT, Garcia QS (2012) The effects of arsenic on the growth and nutritional status of Anadenanthera peregrina, a Brazilian savanna tree. J Plant Nutr Soil Sci 175:466-473. https://doi.org/10.1002/jpln.201100195

Huang JH, Matzner E (2006) Dynamics of organic and inorganic arsenic in the solution phase of an acidic fen in Germany. Geochim Cosmochim Ac 70:2023-2033. https://doi.org/10. 1016/j.gca.2006.01.021

Huang JH, Matzner E (2007) Mobile arsenic species in unpolluted and polluted soils. Sci Total Environ 377:308-318. https://doi.org/10. 1016/j.scitotenv.2007.01.059

Jedynak L, Kowalska J, Kossykowska M, Golimowski J (2010) Studies on the uptake of different arsenic forms and the influence of sample pretreatment on arsenic speciation in White mustard (Sinapis alba). Microchem J 94:125-129. https://doi.org/ 10.1016/j.microc.2009.10.001

Kuehnelt D, Lintschinger J, Goessler W (2000) Arsenic compounds in terrestrial organisms. IV. Green plants and lichens from an old arsenic smelter site in Austria. Appl Organomet Chem 14:411-420. https://doi.org/10.1002/1099-0739(200008)14:8<411::AID$\mathrm{AOC} 24>3.0 . \mathrm{CO} ; 2-\mathrm{M}$

Kumar V, Vogelsang L, Seidel T, Schmidt R, Weber M, Reichelt M, Meyer A, Clemens S, Sharma SS, Dietz KJ (2018) Interference between arsenic-induced toxicity and hypoxia. Plant Cell Environ. https://doi.org/10.1111/pce.13441

Li N, Wang J, Song WY (2016) Arsenic uptake and translocation in plants. Plant Cell Physiol 57:4-13. https://doi.org/10.1093/ $\mathrm{pcp} / \mathrm{pcv} 143$

Liao X, Ma X, Yan X, Lin L, Shi P, Wu Z (2016) Transportation and localization of phenanthrene and its interaction with different species of arsenic in Pteris vittata L. Chemosphere 153:307-314. https://doi.org/10.1016/j.chemosphere.2016.03.071

Lomax, C., 2013. Investigating the origin and transport of methylated arsenic species in plants. $\mathrm{PhD}$ thesis. University of Aberdeen

Ma JF, Yamaji N, Mitani N, Xu XY, Su YH, McGrath SP, Zhao FJ (2008) Transporters of arsenite in rice and their role in arsenic accumulation in rice grain. Proc Natl Acad Sci 105:9931-9935. https://doi.org/10. 1073/pnas.0802361105

Mandal BK, Suzuki KT (2002) Arsenic round the world: a review. Talanta 58:201-235. https://doi.org/10.1016/S00399140(02)00268-0

Marin AR, Masscheleyn PH, Patric WH (1992) The influence of chemical form and concentration of arsenic on rice growth and tissue arsenic concentration. Plant Soil 139:175-183. https://doi.org/10. 1007/BF00009308

Marin AR, Pezeshki SR, Masschelen PH, Choi HS (1993) Effect of dimethylarsenic acid (DMAA) on growth, tissue arsenic, and photosynthesis of rice plants. J Plant Nutr 16:865-880. https://doi.org/ $10.1080 / 01904169309364580$

Meharg AA, Hartley-Whitaker J (2002) Arsenic uptake and metabolism in arsenic resistant and nonresistant plant species. New Phytol 154: 29-43. https://doi.org/10.1046/j.1469-8137.2002.00363.x

Mishra S, Mattusch J, Wennrich R (2017) Accumulation and transformation of inorganic and organic arsenic in rice and role of thiolcomplexation to restrict their translocation to shoot. Sci Rep 7: 40522. https://doi.org/10.1038/srep40522

Mitra A, Chatterjee S, Gupta DK (2017) Uptake, transport, and remediation of arsenic by algae and higher plants. In: Gupta DK, Chatterjee $\mathrm{S}$ (eds) Arsenic contamination in the environment. Springer, Cham, pp 145-169. https://doi.org/10.1007/978-3-319-54356-7_7 
Mohamed H, Abbas H, Meharg AA (2008) Arsenate, arsenite and dimethyl arsenic acid (DMA) uptake and tolerance in maize (Zea mays L.). Plant Soil 304:277-289. https://doi.org/10.1007/s11104008-9549-9

Niedzielski P, Mleczek M, Magdziak Z, Siwulski M, Kozak L (2013) Speciation of As(III), As(V) and dimethylarsenic acid (DMAA) in Xerocomus badius fruiting bodies. Food Chem 141:3571-3577. https://doi.org/10.1016/j.foodchem.2013.06.103

Nigra AE, Nachman KE, Love DC, Grau-Perez M, Navas-Acien A (2017) Poultry consumption and arsenic exposure in the US population. Environ Health Perspect 125:370-377. https://doi. org/10.1289/EHP351

Paul S, Chakraborty S, Ali MN, Ray DP (2015) Arsenic distribution in environment and its bioremediation: a review. Int $\mathrm{J}$ Agric Environ Biotechnol 8:189-204. https://doi.org/10.5958/2230732X.2015.00025.X

Phillips DJH (1990) Arsenic in aquatic organisms: a review of emphasizing chemical speciation. Aquat Toxicol 16:151-186. https://doi.org/ 10.1016/0166-445X(90)90036-O

Raab A, Williams PW, Meharg AA, Feldmann J (2007) Uptake and translocation of inorganic and methylated arsenic species by plants. Environ Chem 4:197-203. https://doi.org/10.1071/EN06079

Rahman SM, Matsumuro T, Miyake H, Takeoka Y (2001) Effects of salinity stress on the seminal root tip ultrastructures of rice seedlings (Oryza sativa L.). Plant Prod Sci 4:103-111. https://doi.org/10. $1626 /$ pps.4.103

Rasas-Castor JM, Guzman-Mar JJ, Hernandez-Ramirez A, GarzaGonzalez MT, Hinojosa-Reyes L (2014) Arsenic accumulation in maize crop (Zea mays): a review. Sci Total Environ 488-489:176187. https://doi.org/10.1016/j.scitotenv.2014.04.075

Sadee BA, Foulkes ME, Hill SJ (2016) A study of arsenic speciation in soil, irrigation water and plant tissue: a case study of the broad bean plant, Vicia faba. Food Chem 210:362-370. https://doi.org/10.1016/ j.foodchem.2016.04.066

Santra SC, Samal AC, Bhattacharya P, Banerjee S, Biswas A, Majumdar J (2013) Arsenic in foodchain and community health risk: a study in Gangetic West Bengal. Procedia Environ Sci 18:2-13. https://doi. org/10.1016/j.proenv.2013.04.002

Singh R, Singh S, Parihar P, Singh VP, Prasad SM (2015) Arsenic contamination, consequences and remediation techniques: a review. Ecotox Environ Safe 112:247-270. https://doi.org/10.1016/j. ecoenv.2014.10.009

Suriyagoda LD, Ditter K, Lambers H (2018) Mechanism of arsenic uptake translocation and plant resistance to accumulate arsenic in rice grains. Agric Ecosyst Environ 253:23-37. https://doi.org/10.1016/j. agee.2017.10.017

Szákova J, Tlustoš P, Goessler W, Pavlkov D, Schmeisser E (2007) Response of pepper plants (Capsicum annum L.) on soil amendment by inorganic and organic compounds of arsenic. Arch Environ Contam Toxicol 52:38-46. https://doi.org/10. 1007/s00244-005-0250-1

Takamatsu T, Aoki H, Yoshida T (1982) Determination of arsenate, arsenite, monomethylarsonate, and dimethylarsinate in soil polluted with arsenic. Soil Sci 133:239-246

Tang Z, Kang Y, Wang P, Zhao FJ (2016) Phytotoxicity and detoxification mechanism differ among inorganic and methylated arsenic species in Arabidopsis thaliana. Plant Soil 401:243-257. https://doi.org/ 10.1007/s11104-015-2739-3

Tlustoš P, Goessler W, Szakova J, Balik J (2002) Arsenic compounds in leaves and roots of radish grown in soil treated by arsenite, arsenate and dimethylarsinic acid. Appl Organomet Chem 16:216-220. https://doi.org/10.1002/aoc.282

Upadhyay MK, Shukla A, Yadav P, Srivastava S (2018) A review of arsenic in crops, vegetables, animals and food products. Food Chem 276:608-618. https://doi.org/10.1016/j.foodchem.2018.10.069

Yamanaka K, Kato K, Mizoi M, An Y, Takabayashi F, Nakano M, Hoshino M, Okada S (2004) The role of active arsenic species produced by metabolic reduction of dimethylarsinic acid in genotoxicity and tumorigenesis. Toxicol Appl Pharmacol 198: 385-393. https://doi.org/10.1016/j.taap.2003.10.025

Yanitch A, Brereton NJB, Gonzales E, Labrecque M, Joly S, Pitre FE (2017) Transcriptomic response of Purple Willow (Salix purpurea) to arsenic stress. Front Plant Sci 8:1115. https://doi.org/10.3389/fpls. 2017.01115

Yao LX, Li GL, Dang Z, He ZH, Zhou CM, Yang BM (2009) Arsenic speciation in turnip as affected by application of chicken manure bearing roxarsone and its metabolites. Plant Soil 316:117-124. https://doi.org/10.1007/s11104-008-9764-4

Ye WL, Wood BA, Stroud JL, Andralojc PJ, Raab A, McGrath SP, Feldmann J, Zhao FJ (2010) Arsenic speciation in phloem and xylem exudates of castor bean. Plant Physiol 154:1505-1513. https:// doi.org/10.1104/pp.110.163261

Yoon Y, Lee WM, An YJ (2015) Phytotoxicity of arsenic compounds on crop plant seedlings. Environ Sci Pollut Res 22:11047-11056. https://doi.org/10.1007/s11356-015-4317-x

Zaccone C, Lobianco D, Raber G, D'Orazio V, Shotyk W, Miano TM, Francesconi K (2018) Methylated arsenic species throughout a 4-m deep core from a free-floating peat island. Sci Total Environ 621:6774. https://doi.org/10.1016/j.scitotenv.2017.11.152

Zhang J, Zhao QZ, Duan GL, Huang YC (2010) Influence of sulphur on arsenic accumulation and metabolism in rice seedlings. Environ Exp Bot 72:34-40. https://doi.org/10.1016/j.envexpbot.2010.05.007

Zhang L, Qin X, Tang J, Liu W, Yang H (2017) Review of arsenic geochemical characteristic and its significance on arsenic pollution studies in karst groundwater, Southwest China. Appl Geochem 77: 80-88. https://doi.org/10.1016/j.apgeochem.2016.05.014 